\title{
What about Us? Measuring the Work-Life Balance of People Who Do Not Have Children
}

\author{
Julie A. Waumsley \\ Lecturer of Psychology, Division of Psychology, The University of Northampton \\ NN2 7AL, U.K. \\ Tel: 44-1604-892378Ｅ-mail: julie.waumsley@northampton.ac.uk \\ Diane M. Houston \\ Professor of Psychology, Dean of the Graduate School \\ Keynes College, The University of Kent \\ Canterbury, Kent, CT2 7NP, U.K. \\ Tel: 44-1227-827933Ｅ-mail: D.M.Houston@kent.ac.uk \\ Gillian Marks \\ Lecturer of Psychology, Centre for Psychology Studies \\ Department of Social Sciences and Humanities, The University of Bradford \\ West Yorkshire, BD7 1DP, U.K. \\ Tel: 44-1274-233514Ｅ-mail: G.Marks1@Bradford.ac.uk
}

This research is supported by The University of Kent, United Kingdom

\begin{abstract}
To date, the work-family literature has examined conflict between work and family and family and work. In this research the use of the word "family" usually denotes child-care responsibilities. Furthermore, scales developed to measure conflict have concentrated on a family structure defined in this way. Little is known about conflict between work and non-work experienced by people who do not live within a family structure that includes children. The aim of this paper is to examine whether existing work-family and family-work conflict measures might be adapted to measure work-life conflict and life-work conflict for full-time female workers $(\mathrm{N}=940)$ with and without children. Results suggest that a work-family conflict scale may not adequately measure the conflicts experienced by people who do not live within a family structure that involves children. The implications of these findings are further discussed with suggestions concerning the feasibility of using a generic work-life scale to measure work-life balance and a specific work-family scale to measure work-family balance.
\end{abstract}

Keywords: Work-life balance, Work-family conflict, Family-work conflict, Scale, Measurement

\section{Introduction}

Work and family life are not always compatible and conflicts between the two domains are often experienced (e.g.Houston \& Waumsley, 2003; Linehan \& Walsh, 2000, 2001; Somech \& Drach-Zahavy, 2007; Bakker, Demerouti \& Dollard, 2008). Since the launch of the UK Government's work-life balance campaign in 2000, a plethora of research has ensued, examining work-family conflict, family-work conflict and flexible working (e.g. Eby et al., 2005; Bakker, Demerouti \& Dollard, 2008; Hornung, Rousseau \& Glaser, 2008; Houston \& Waumsley, 2003; Lyness \& Judiesch, 2008; Valcour, 2007) and the Government are continually reviewing their flexible working and work-life balance strategies (BERR, 2007). To date, the work-family literature has examined conflict between work and family and family and work. Much of this research defines a family as a unit which includes children and so brings with it issues of child care responsibilities. Little is known about 
conflict between work and non-work experienced by people who live within a family structure that does not include children. Furthermore, scales developed to measure work-life conflict have also concentrated on work and families that include children (e.g. Carlson, Kacmar, \& Williams, 2000; Frone, Russell \& Cooper, 1992a; Netemeyer, Boles \& McMurrian, 1996).

The omission of people who do not live within a traditional family structure with children is important given that the picture is one of a gradual decline in the number of married people in the UK: Since 1978 the proportion of people who are married has declined, from 50 per cent in mid-1978 to 40 per cent in mid-2008. At the same time the proportion of people who are divorced has risen, from 2 per cent in mid-1978 to 7 per cent in mid-2008 (ONS, 2010). The median age of marriage in the UK is increasing for both men and women. In 1952, the average age for first marriage for men was 25.1 years, and for women, 22.5 years. In 2006, this had risen to 31.8 years and 29.7 years respectively (ONS, 2008). The number, in thousands, of men in this age group in employment in 2008 in the UK was 3294; for women the figure stood at 2775 (LFS, 2008). In addition, figures suggest that four out of ten single women in their thirties (39 per cent) do unpaid overtime work, whilst the same figure for single men in their thirties stands at 26 per cent. The proportion of women doing unpaid overtime drops significantly to 17 per cent when they have children. For men with children the overtime figure only marginally falls to 21.7 per cent (TUC, 2008). Whilst there has been a dramatic growth in the number of one-parent households from $9 \%$ in 1971 to $25 \%$ in 2001 (LFS, 2005), what is perhaps more exceptional is the continuing growth in one-person households in the UK, which has doubled since 1971 and is set to rise by fifty-three per cent over the next twenty years (Alliance \& Leicester, 2006). Many of these new households are in the twenty-five to sixty-four age groups. In addition, the increase in the pension age is likely to lead to many more older people to continue to work after their children have left home. Given these changing demographics, it is important to understand the way that people who do not live within a family environment that includes children are able to balance work and life outside work, especially when there is evidence to suggest childfree single people work more when employees with families want time off (Scott, 2001). Furthermore, employees who want to work flexibly to enable more time for the pursuit of leisure activities are considered less committed and more likely to leave their organisation than those who work flexibly because of child care (Waumsley, 2005). In the UK's third work-life balance Governmental survey (Hooker, Neathey, Casebourne \& Munro, 2007) 38 per cent of employees admitted negative consequences to colleagues working flexibly, whist 53 per cent of employees agreed that people working flexibly created more work for others. Given that 78 per cent of employees use flexible working, the majority of whom are women (CIPD, 2005), and given that the responsibility for child care and domestic responsibilities still falls to women (Houston \& Marks, 2002; 2005; Houston \& Waumsley, 2003; White, 2004) it is likely that the majority of employees using flexible working options are women with child care responsibilities. Thus, it is important to better understand the ways in which being able to balance work with life away from work occurs for employees who live outside a family structure that includes children.

Research in the USA (Casper, Weltman \& Kwesiga, 2007) examined the way in which single employees with no children perceived support for work-life balance in their organisations compared to employees with families. Findings showed that single employees perceived less equity in social inclusion, work opportunities, access to benefits, respect for non-work life and work expectations than did employees with families, suggesting support for work-life issues is important to a diverse range of employees. These findings provide strong evidence that organisations should enhance work benefit packages that attract all sectors of society. However, there is very little research to inform such changes; whilst there is much research suggesting the success of family-friendly policies in organisations (e.g. Allen, 2001; Behson, 2002; CIPD, 2005; Hooker et al., 2007; Houston \& Waumsley, 2003) where a work-family culture relates to desirable outcomes for employees with families. In the UK there is a paucity of research which explicitly addresses the issues for employees who do not live within a family structure that includes children. Measuring work-family and family-work conflict implicitly assumes that only people who live within a family structure and have children experience conflict between work and life outside work. However, people who do not live within such a family structure may still experience conflict between work and other aspects of their lives. For these individuals, measuring work-family and family-work conflict may not capture this.

\subsection{Aim of this study}

The aim of this study was to examine whether existing work-family (WFC) and family-work conflict (FWC) measures (Netemeyer, et al., 1996) could be adapted by subtle changes in wording to measure work-life (WLC) and life-work conflict (LWC) for women with and without children. It was decided to focus on women given the 
evidence that suggest women's hours of work drop significantly more than those of men when they have children (TUC, 2008) and given the rise of single-person households in the UK (Alliance \& Leicester, 2006).

The conceptual approach taken in the development of the five item scales by Netemeyer, et al., (1996) was based on the premise that WFC and FWC are distinct but related forms of interrole conflict (Greenhaus \& Beutell, 1985; Kahn, 1981), where interrole conflict occurs when role responsibilities from the work and family domains are incompatible. As such, the demands of one domain role make performance in another domain role more difficult. Most workers report family to be more important than work, and research indicates that more WFC is experienced than FWC (Burke \& Greenglass, 2001; Frone, Russell \& Cooper, 1997; Houston \& Waumsley, 2003, Somech \& Drach-Zahavy, 2007).

The study was designed to examine the relationship between the WFC and FWC scales of Netemeyer, et al., (1996) and an adapted version of these to measure WLC and LWC scales by using slight adjustments to item wording. It also drew on previous findings from Houston and Waumsley (2003) where organisational identity, turnover intention, organisational culture and psychological health were all shown to be related to conflict with employees in the manufacturing sector. Findings showed that, whilst very few workers (7 per cent) reported that their family life caused conflict with their work, 45 per cent of full-time workers experienced conflict caused by work interfering with their family or personal life. Houston and Waumsley (2003) also showed a non-supportive workplace culture to be associated with higher levels of work-family conflict, increased turnover intentions and poorer psychological health. Psychological stress was strongly related to work-family conflict but somewhat less to family-work conflict, and turnover intention was strongly associated with work-family conflict. Using WFC, FWC, WLC and LWC scales in this study will allow examination of patterns of relationships with organisational identity, turnover intention, organisational culture and psychological health between people who do and do not have childcare responsibilities and thus might be considered to either live within or outside of what is considered to be a family structure.

\subsection{Justification for using the Netemeyer, et al., (1996) scales}

The scales developed by Netemeyer, et al., (1996) have been subjected to rigorous scale development, showing internal consistency across three samples (high school teachers, small business owners, and real estate sales people) and showed reliability on short 'user friendly' scales. Netemeyer, et al., (1996) also acknowledged the conceptual distinction between WFC and FWC and reflects aspects of work or family interfering when performing the opposite domain duties, rather than reflecting outcomes of the constructs themselves.

It was expected that exploratory factor analysis would suggest that the structure of the WFC/FWC scales of Netemeyer, et al., (1996) and the adapted WLC/LWC scales would be similar and that confirmatory factor analysis would confirm this hypothesis. It was predicted that the Pearson correlations would show organisational identity to be negatively related to WFC and WLC. In contrast, turnover intention and WFC and WLC were predicted to be positively related. Organisational culture was predicted to be negatively related to WFC/FWC and WLC/LWC, especially for those with children. It was predicted that psychological distress would be positively related to WFC/FWC and WLC/LWC. It was also predicted that there would be differences between whether or not people had children and the amount of WFC/WLC and FWC/LWC they experienced. The changes in 'family' and 'life' wording were expected to show some differences between those with and without children in terms of the amount of conflicts experienced, which would indicate some variations in the construct validity between the two scales.

\section{Method}

\subsection{Participants}

Participants were 940 female trade union members; 610 from Union 1 (a 20 per cent response rate) and 330 from Union 2 (a 30 per cent response rate). All worked full-time. Female participants from Union 1 worked in a predominantly male culture of electrical and mechanical engineering workers, although were typically office support staff. Female participants from the Union 2 worked in the public services, the voluntary and private sectors, and were office-based workers. Demographics for participants from both unions are shown in Table 1.

Insert Table 1 about here 


\subsection{Materials}

In the Union 1 questionnaire, WFC and FWC were measured with the original scales developed by Netemeyer, et al., (1996). The instructions that preceded these items were as follows: "The next set of questions are about your personal experiences of work and family life. 'Family' may be your partner, children, parents, brothers and sisters, grandparents, or any combination of these. Please think of family as best fits your own personal circumstances and try to answer these questions, even if you do not have any close family." All items were measured using a 7-point Likert scale, with 1 meaning strongly disagree and 7 meaning strongly agree. The items are shown in Table 2.

Insert Table 2 about here

In the Union 2 questionnaire, WLC and LWC were measured using adaptations of the original scales developed by Netemeyer, et al., (1996) with changes in wording. The instructions that preceded these items were as follows: "How far do you agree or disagree with the following statements." All items were measured using a 7-point Likert scale, with 1 meaning strongly disagree and 7 meaning strongly agree. The items are shown in Table 3.

Insert Table 3 about here

In addition to the WFC and FWC, and WLC and LWC scales, both questionnaires included identical scales to measure organisational identity, turnover intention, organisational culture and psychological health. All items except psychological health were measured using a 7-point Likert scale. Psychological health was measured on a scale from 0 to 3 .

\subsubsection{Evaluation Scales}

Organisational identity (Abrams, Ando \& Hinkle, 1998) was measured using five items (e.g. I feel strong ties with my organisation). Cronbach's Alpha $=.95$

Turnover intention (Abrams, et al., 1998) was measured using three items (e.g. I think about leaving this organisation). Cronbach's Alpha $=.81$

Organisational Culture (Thompson, Beauvais \& Lyness, 1999) was measured using twenty items (e.g. My direct manager is sympathetic to family-related needs). Cronbach's Alpha $=.88$

Psychological well-being was measured using the General Health Questionnaire (Goldberg \& Hillier, 1979) a twelve-item measure of psychological distress (e.g. Have you recently been feeling unhappy and depressed). Cronbach's Alpha $=.96$

\subsection{Design and Procedure}

To examine the relationship between conflicts using the scales described, two questionnaire surveys were administered with two large UK trade unions (Union 1 and Union 2) to provide a large sample of workers across organisations.

\section{Results}

\subsection{Exploratory Factor Analysis}

To investigate whether changes in wording to the WLC and LWC scales altered the factor structure from the WFC and FWC scales identified by Netemeyer, et al., (1996), principle components analysis with varimax rotation was carried out on the data from Union 1 female full-time workers $(\mathrm{N}=610)$ and Union 2 female full-time workers $(\mathrm{N}=330)$. Both supported the same two-factor solution developed and validated by Netemeyer, et al., (1996). These components are shown in Tables 4 and 5.

Insert Table 4 about here 
Insert Table 5 about here

\subsection{Confirmatory Factor Analysis}

To follow exploratory factor analysis, and to test the hypothesis that the factor structure of the 'life' scales supported the same two-factor solution as that of the 'family' scales developed and validated by Netemeyer, et al., (1996), confirmatory factor analysis was conducted on the WLC, LWC, WFC and FWC scales. Multicolinearity, as measured by the determinant of the input matrix was 14.65 and 1521.7 respectively. The variables therefore were not linearly related in either case. The standardised residual matrix showed all correlations between the variables to be close to zero for all scales. The independence model chi-square that tests the hypothesis that the variables are uncorrelated with one another was rejected, $\chi^{2}(45, \mathrm{~N}=325)=2006.77, \mathrm{p}$ $<.001$ and $\chi^{2}(45, \mathrm{~N}=605)=2791.09, \mathrm{p}<.001$ respectively. Although the chi-square hypothesised model indicated an improvement in fit in comparison to the independent model in both cases, $\chi^{2}(34, \mathrm{~N}=325)=109.49$, $\mathrm{p}<.001$ and $\chi^{2}(34, \mathrm{~N}=605)=153.42, \mathrm{p}<.001$ respectively, it did not allow the null hypotheses to fail to be rejected. However, as noted by Bentler (1990a) the chi-square test is not as sensitive a test as are the fit-indices when using large sample sizes, and often causes trivial differences to produce statistically significant chi-square results. Inspection of the other fit indices indicated the solution fitted the data well, with the goodness of fit index ranging from .90 to .96 in both cases. All comparative fit indices and residual-based fit indices are shown in Table 6.

Insert Table 6 about here

\subsection{Pearson Correlation}

Pearson correlation was carried out to examine patterns of relationships between WFC/FWC and WLC/LWC and organisational identity, turnover intention, organisational culture and psychological health for female workers with and without childcare responsibilities in both Unions (Table 7).

Insert Table 7 about here

The relationships between the variables shown in Union 1 indicate no differences between female full-time workers with children and female full-time workers without children. This same pattern of correlations is shown for Union 2 with the following exceptions. Organisational identity and work-life conflict are not significantly correlated for those with children. Organisational identity and life-work conflict are significantly negatively related. For those with children, turnover intention and life-work conflict are significantly positively correlated. For those without children, life-work conflict and psychological health are not related.

\subsection{Fisher's $z$ r Transformations}

Results of Fisher's $\mathrm{z} r$ transformation showed that the two correlations for those with children (Union 1 $\mathrm{WFC} / \mathrm{FWC} \mathrm{r}=.467$; Union $2 \mathrm{WLC} / \mathrm{LWC} \mathrm{r}=.329$ ) were not significantly different, $\mathrm{z}=1.60$, n.s. (two-tailed). Results also showed that the two correlations for those without children (Union $1 \mathrm{WFC} / \mathrm{FWC} \mathrm{r}=.408$; Union 2 $\mathrm{WLC} / \mathrm{LWC} \mathrm{r}=.385$ ) were not significantly different, $\mathrm{z}=0.29$, n.s. (two-tailed). To test whether the relationships, and thus, the wording between 'Family' and 'Life', differed between the other constructs for those with and without children, Fisher's z r transformations were again conducted (Table 8).

Insert Table 8 about here

For people with children, the z scores between FWC and psychological health and LWC and psychological health were significantly different, $\mathrm{z}=1.94, \mathrm{p}<.05$ (two-tailed). Whilst there was a significant relationship between the amount of conflict between 'family' and work and psychological distress, and also between 'life' and work and psychological distress, people reported significantly more conflict between 'family' and work than between 'life' and work. 


\subsection{Multivariate Analysis}

Union 1 and Union 2 data sets were merged. Multivariate analysis showed significant differences between whether or not people had children and the amount of WFC/WLC experienced, $F(1,925)=8.58, p<.01, M s=$ 2.93. Significant differences were also found between WFC/WLC, $F(1,925)=9.67, p<.01, M s=2.93$ and FWC/LWC, $F(1,925)=12.63, p<.001, M s=1.42$. A two-way interaction effect was found between FWC/LWC and whether or not people had children, $F(1,925)=4.39, p<.05, M s=1.42$.

Pairwise comparisons showed significant differences between WFC $(M=3.56, S D=1.66)$ and WLC $(M=4.07$, $S D=1.83$ ) with women who do not have children, $p<.01$. Women who work full-time and do not have children experience significantly more conflict from work into their lives generally, than conflict that is experienced from work into family life. Significant differences were also found between FWC $(M=2.61, S D=1.30)$ and LWC ( $M$ $=2.12, S D=1.18$ ) between women who work full-time and do have children, $p<.001$. Women who work full-time and have children experience significantly more conflict from family into their work than conflict from life generally into work.

It is acknowledged that the unions may themselves have created differences. Results from MANOVA showed a main effect for FWC/LWC between Union 1 and Union $2, F(1,2056)=27.99, p<.001, M s=1.40$. Women in Union 1 experienced significantly more FWC $(M=2.49, S D=1.19)$ than LWC experienced by women in Union $2(M=2.13, S D=1.16)$. Results also showed a main effect for WFC/WLC for women with children, $F(1,2056)$ $=11.34, p<.001, M s=2.78$. In both unions, women with children experienced more WFC/WLC $(M=4.27, S D$ $=1.65)$ than did women without children $(M=3.82, S D=1.68)$. No interaction effect was found between union and having children.

\section{Discussion}

This study suggests that a work-family conflict scale may not adequately measure the conflicts experienced by people who do not live within a family structure that includes children. What has been identified is a scale that measures work-life conflicts, but which, in turn, may not be entirely suitable for measuring work-family conflicts.

\subsection{The findings of the study}

The aim of this study was to examine the relationship between the WFC (work-family conflict) and FWC (family-work conflict) scales of Netemeyer, et al., (1996) and the WLC (work-life conflict) and LWC (life-work conflict) scales adapted from the Netemeyer, et al., (1996) scales when the item wording had been changed. The factor structure of the 'life' scales supported the same two-factor solution as that of the 'family' scales developed and validated by Netemeyer, et al., (1996). The fit indices resulting from confirmatory factor analysis indicated the solution fitted the data well.

Pearson correlation showed similar relationships between variables with both unions. In Union 1, for women with and without children, organisational identity was negatively related to WFC, showing that the more identified people are with their organisation, the less WFC they have. There was a negative, but not significant, correlation between organisational identity and FWC. In Union 2, organisational identity and WLC were not significantly related for those with children. Furthermore, organisational identity and LWC were significantly negatively related, showing that the more people are identified with their organisation, the less LWC they have.

It was expected that the more WFC people experience, the more they are likely to want to leave their organisation concurring with the findings of Houston \& Waumsley (2003). Indeed, for those with and without children in Union 1 and Union 2, this was supported by a positive relationship between turnover intention and WFC. The relationship between turnover intention and FWC was not significant for those with and without children in Union 1. For those with children in Union 2, turnover intention and LWC were positively related, showing that the more LWC people have, if they have children, the more likely they are to want to leave their organisation. The same relationship in Union 2 for those without children was not significant.

Organisational culture was negatively related to WFC/WLC and FWC/LWC in both unions for people with and without children, showing that the more work-family/life and family/life-work conflicts experienced, the less positively people feel their organisation is towards flexible working policies. This is entirely in keeping with the findings of Houston and Waumsley (2003) who also showed a non-supportive workplace culture to be associated with higher levels of work-family conflict.

In both unions, for those with and without children, WFC/WLC and FWC/LWC were positively related, showing that the greater the WFC/WLC experienced, the greater the FWC/LWC also experienced. It was expected that greater levels of psychological distress would be associated with higher levels of conflicts (Frone 
\& Yardley, 1996; Houston \& Waumsley, 2003). In Union 1, for those with and without children, WFC and FWC were both significantly positively related to psychological distress. However, in Union 2, whilst WLC was significantly positively related to psychological distress, and LWC was significantly positively related to psychological distress for those with children, LWC and psychological distress were not related for those without children.

Based on Fisher's transformation, z-tests confirmed the difference for those with children between FWC and psychological distress and LWC and psychological distress as significant. People with children reported significantly more conflict between family and work than between life and work.

Mulitvariate analysis showed that women who work full-time and do not have children experience significantly more conflict from work into their lives generally, than conflict that is experienced from work into family life. Women who work full-time and do have children experience significantly more conflict from family into their work than conflict from life generally into work. Differences between unions showed women in Union 1 experienced significantly more FWC than LWC experienced by women in Union 2. In both unions, women with children experienced more WFC/WLC than women without children.

\subsection{Meaning and Implications of the Findings}

The relationship between organisational identity and WFC for women with and without children is perhaps not surprising. It might be that people experience less conflict between work and family the more identified they are with their organisation, or that the more identified they are with their organisation the less work-family conflict they experience. Either way, role theory might explain this relationship. A greater identity with an organisational role might mean that there does not appear to be a clash in roles between work and family, or that any clash is not perceived as conflicting. This explanation is given some credibility by the positive relationship between WFC and turnover intention for those with and without children and by a negative relationship between organisational identity and turnover intention. Whilst these relationships do not suggest a causal inference is appropriate, it may be that high organisational identity suggests less LWC and less intention to leave that organisation. The negative relationship between organisational culture and WFC/WLC and FWC/LWC in both unions for people with and without children lends support to the findings on organisational identity and turnover intention. These relationships support those found in previous studies (e.g. Houston \& Waumsley, 2003).

The relationship between conflict and psychological distress is problematic in the context of attempts to develop a generic scale. Previous research has shown an increase in conflict to be positively related to psychological distress (e.g. Frone, et al., 1992a; Houston \& Waumsley, 2003). Whilst in this study, for those with children, there was a significant positive relationship between FWC and psychological distress in Union 1 and also between LWC and psychological distress in Union 2, the difference between the correlations was significant. People reported significantly more conflict between 'family' and work than between 'life' and work. Thus, for those with children, there is a relationship between family-based conflict and psychological distress that is not completely captured /adequately measured by a more generic scale. This may suggest that, for people with children, there is a distinction to be made between family related conflict and life-related conflict, with the former causing greater psychological distress.

The difference between family life and life generally was again highlighted by the finding in both unions that women without children report more WLC than WFC. Again, this may be because work is 'allowed' to intrude more into 'life' than into 'family'. Women with children report more FWC than LWC. This is intuitively plausible and may again be due to it being more acceptable for 'family' to conflict with work than 'life' generally to conflict with work. Another explanation for the differences may be because they are the result of differences between the two unions. Union 1 was very male dominated, which may have made some difference to the amount of stress experienced. Certainly women in Union 1 reported more FWC than those in Union 2 reported LWC. However, there was no significant difference between unions and those with childcare. In both unions, women with children reported more WFC/WLC than women without children. It therefore seems that the difference in the samples may be causing the differences between FWC and LWC rather than the different wording (family or life). It is plausible to suggest that if the wording was being interpreted differently, there would be an interaction for union and childcare since people with children report more conflict. Conversely, it might be argued that differences between WFC and WLC for women without children, and between FWC and LWC for women with children imply that the changes in wording indicate different things. The interpretation of 'life' appears to be different from that of 'family' when the conflict is from non-work to work.

The relationships between conflicts and organisational identity, turnover intention, organisational culture and psychological health supported the findings of Houston and Waumsley (2003), supporting the construct validity 
of the more generic scale. However, differences between the 'family' and 'life' wording imply some variations in the construct validity of the two scales, particularly between FWC and LWC, which appear to be measuring different constructs. The $\mathrm{z} r$ transformation showing a significant difference between FWC and psychological health and LWC and psychological health for those with children is further evidence to suggest that the wording created a different response. Interestingly, it is 'family' and not 'life' that appears to have an impact on psychological health. Whilst the reliability of the WLC and the LWC scales are high, the two constructs, 'family' and 'life', appear to have been perceived differently. Notwithstanding this, the Fisher's z $r$ transformations for all other variables did not show significant differences between the two sub-scales, showing that the WFC/FWC and WLC/LWC scales had similar relationships with other scales in the study. Psychological health was the exception. This strengthens the argument for the continued adaptation of the WFC/FWC scale in order that it recognises people who do not live as part of a family that includes children.

\section{Conclusion}

The implications of this study are that a WFC/FWC scale may not adequately measure the conflict experienced in the lives of people who do not live as part of a family that includes children and a WLC/LWC scale may not adequately measure the conflicts of those who do. This is problematic since, as this study has demonstrated, FWC has a stronger relationship with psychological distress than LWC. Perhaps the answer lies in future research using a new scale, consisting of four sub scales: WFC, FWC, WLC, and LWC, made up of the three top loading items from each. Such a scale would allow a more detailed examination of the family, work and life based antecedents of psychological distress and, potentially, a more targeted response. Further development of this new scale is suggested for future research, extending the population to males as well as females. Conversely, if a study is particularly interested in examining families with children, the WFC/FWC scale might be used. If not, the more generic scale may be more meaningful. The WLC/LWC scale might ensure a more sensitive measurement of conflict between work and life outside work for people who do not live as part of a family with children. It is important, both empirically and socially, to accurately measure the conflicts experienced by people between work and life outside work since one of the aims of the British government's work-life balance campaign is to encourage work-life balance for all.

\section{References}

Abrams, D., Ando, K., \& Hinkle, S.W. (1998). Psychological attachment to the group: Cross-cultural differences in organizational identification and subjective norms as predictors of workers' turnover intentions. Personality and Social Psychology Bulletin, 24, 1027-1039.

Allen, T. D. (2001). Family-supportive work environments: The role of organizational perceptions. Journal of Vocational Behavior, 58, pp.414 - 435.

Alliance \& Leicester. (2006). Changing UK Household Market. [Online] Available: http://www.marketresearch.com/map/prod/1486958.html (27th August 2008).

Bakker, A.B., Demerouti, E. \& Dollard, M.F. (2008). How job demands affect partners' experience of exhaustion: Integrating work-family conflict and crossover theory. Journal of Applied Psychology, 93, (4): 901-911.

Behson, S.J. (2002). Coping with family-to-work-conflict: The role of informal work accommodations to family. Journal of Occupational Health Psychology, 7, 324-341.

Bentler, P.M. (1990a). Comparative fit indexes in structural models. Psychological Bulletin, 107, 238-246.

BERR. (2007). Flexible working: The right to request and the duty to consider. [Online] Available at http://www.berr.gov.uk/employment-legislation/employment-guidance/page35663.html (5th March 2010).

Burke, R.J. \& Greenglass, E.R. (2001). Hospital Restructuring, Work-Family Conflict and Psychological Burnout among Nursing Staff. Psychology and Health, 5: 583-594.

Carlson, D., Kacmar, K., \& Williams, L. (2000). Construction and initial validation of a multidimensional measure of work-family conflict. Journal of Vocational Behavior, 56, (2): 249-276.

Casper, W.J., Weltman, D. \& Kwesiga, E. (2007). Beyond family-friendly: The construct and measurement of singles-friendly work culture. Journal of Vocational Behavior, 70: 478-501.

CIPD. (2005). Flexible working: Impact and implementation. An employer survey (Feb 2005).

Eby, L.T., Casper, W.J., Lockwood, A., Bordeaux, C., \& Brinley, A. (2005). Work and family research in IO/OB: Content analysis and review of the literature (1980-2002). Journal of Vocational Behavior, 66 (1), 124-197. 
Frone, M. R., Russell, M., \& Cooper, M.L. (1992a). Antecedents and outcomes of work-family conflict: Testing a model of the work-family interface. Journal of Applied Psychology, 77: 65 - 78.

Frone, M. R., Russell, M., \& Cooper, M.L. (1997). Relation of work-family conflict to health outcomes: A four-year longitudinal study of employed parents. Journal of Occupational and Organisational Psychology, 70, 325-335.

Frone, M. R., \& Yardley, J.K. (1996). Workplace family-supportive programmes: Predictors of employed parents' importance ratings. Journal of Occupational and Organizational Psychology, 69: 351-366.

Goldberg, D. \& Hillier, V.F. (1979). A scaled version of the General Health Questionnaire. Psychological Medicine, 9, 139-145.

Greenhaus, J. H. \& Beutell, N. (1985). Sources of conflict between work and family roles. Academy of Management Review, 10: 76-88.

Hornung, S., Rousseau, D.M., \& Glaser, J. (2008). Creating flexible work arrangements through idiosyncratic deals. Journal of Applied Psychology, 93, (3): 655-664.

Hooker, H. Neathey, F. Casebourne, J and Munro, M. (2007). The third work-life balance employee survey: Main Findings. Employment relations research series no. 58, DTI.

Houston, D.M. and Marks, G. (2002). Paid and unpaid work in early parenthood. End of award report to the Economic and Social Research Council.

Houston, D.M. and Marks, G. (2005). Working, caring and sharing: Work-life dilemmas in early motherhood. In D.M. Houston (Ed.), Work-life balance in the twenty-first century, pp. 80 - 105, Palgrave Macmillan: UK.

Houston, D.M. \& Waumsley, J.A. (2003). Attitudes to flexible working and family life. Bristol: The Policy Press/Joseph Rowntree Foundation, Family and Work series.

Kahn, R.L. (1981). Work and health. New York: Wiley.

LFS. (2005). Labour Force Survey. Office for National Statistics, London.

LFS. (2008). Labour Force Survey. Office for National Statistics, London.

Linehan, M. \& Walsh, J.S. (2000). Work-family conflict and the senior female international manager. British Journal of Management, 11, pp.S49 - S58.

Linehan, M. \& Walsh, J.S. (2001). Key issues in the senior female international career move: A qualitative study in a European context. British Journal of Management, 12, pp.85 - 95.

Lyness, K.S. \& Judiesch, M.K. (2008). Can a manager have a life and a career? International and multisource perspectives on work-life balance and career advancement potential. Journal of Applied Psychology, 93 (4): 789-805.

Netemeyer, R. G., Boles, J.S., \& McMurrian, R. (1996). Development and validation of work-family conflict and family-work conflict scales. Journal of Applied Psychology, 81: 400-410.

Office for National Statistics. (2010). Population Estimates by Marital Status. UK Snapshot. [Online] Available: http://www.statistics.gov.uk/cci/nugget.asp?id=2312 (12 March 2010).

Office for National Statistics. (2008). Population Change. [Online] Available: http://www.statistics.gov.uk/hub/population/index.html (16th March 2010).

Office for National Statistics. (2005a). Population trends 120, table 1.4, pp. 41-43. [Online] Available: http://www.statistics.gov.uk/downloads/theme_population/PT120_V1.pdf (5th March 2010).

Scott, M.P. (2001). Singles out singles: Structuring employee services to accommodate the dating game. Employee services management association: In the news. [Online] Available: http://www.esmassn.org/news/indexsingles.htm (2nd March 2010).

Somech, A. and Drach-Zahavy, A. (2007). Strategies for coping with work-family conflict: The distinctive relationships of gender role ideology. Journal of Occupational Health Psychology, 12, pp.1 - 19.

Thompson, C. A., Beauvais, L.L., \& Lyness, K.S. (1999). When work-family benefits are not enough: The influence of work-family culture on benefit utilization, organizational attachment, and work-family conflict. Journal of Vocational Behavior, 54: 392-415.

TUC. (2008). Single women in their thirties do more unpaid overtime than anyone else. [Online] Available: http://www.tuc.org.uk/equality/tuc-14351-f0.cfm (5th March 2010). 
Valcour, M. (2007). Work-based resources as moderators of the relationship between work hours and satisfaction with work-family balance. Journal of Applied Psychology, 92, (6): 1512-1523.

Waumsley, J.A. (2005). Work-life balance: A psychological perspective. Doctoral thesis. University of Kent, Canterbury.

White, M. (2004). Work-life balance and the dual-earner paradox. Employment Group Seminar Summer Series 2004, Policy Studies Institute.

Table 1. Demographics for participants from Union 1 and Union 2

\begin{tabular}{|c|c|c|c|c|c|c|c|c|}
\hline & $\begin{array}{l}\text { Mean } \\
\text { Age }\end{array}$ & $\begin{array}{l}\text { Age } \\
\text { range }\end{array}$ & $\begin{array}{l}\% \text { Child- } \\
\text { ren }\end{array}$ & $\begin{array}{l}\% \text { White } \\
\text { British }\end{array}$ & $\begin{array}{c}\% \\
\text { Married }\end{array}$ & $\begin{array}{c}\% \\
\text { Single }\end{array}$ & $\begin{array}{c}\% \\
\text { Cohab }\end{array}$ & $\begin{array}{c}\% \text { Separated, } \\
\text { Divorced, Widowed }\end{array}$ \\
\hline Union 1 & 41 & $17-64$ & 28 & 96 & 52 & 14 & 17 & 16 \\
\hline Union 2 & 39 & $18-64$ & 63 & 96 & 53 & 14 & 12 & 21 \\
\hline
\end{tabular}

Table 2. Items on scales developed by Netemeyer, et al., (1996) to measure WFC and FWC

Work-family and Family-work Conflict Scale

1. The demands of my work interfere with my home and family life.

2. The amount of time my job takes up makes it difficult to fulfil family responsibilities.

3. Things I want to do at home do not get done because of the demands my job puts on me.

4. My job produces strain that makes it difficult to fulfil family duties.

5. Due to work related duties, I have to make changes to my plans for family activities.

1. The demands of my family or spouse/partner interfere with work-related duties.

2. I have to put off doing things at work because of demands on my time at home.

3. Things I want to do at work don't get done because of the demands of my family or spouse/partner.

4. My home life interferes with my responsibilities at work such as getting to work, accomplishing daily tasks, and working overtime.

5. Family-related strain interferes with my ability to perform job-related duties. 
Table 3. Items on scales developed by Netemeyer, et al., (1996) to measure WLC and LWC

Work-life and Life-work Conflict Scales

1. The demands of my work interfere with my life away from work.

2. The amount of time my job takes up makes it difficult to fulfil other interests.

3. Things I want to do at home do not get done because of the demands of my job.

4. My job produces strain that makes it difficult to fulfil other responsibilities and duties.

5. Due to work, I have to make changes to my plans for activities away from work.

1. The demands of my personal life interfere with work-related duties.

2. I have to put off doing things at work because of demands on my time outside work.

3. Things I want to do at work don't get done because of the demands of my interests outside work.

4. My home life interferes with my responsibilities at work.

5. Personal life strains interfere with my ability to perform work-related duties.

Table 4. Principle components analysis with varimax rotation producing two discrete factors for WFC and FWC from the Netemeyer, et al., (1996) scale. Union 1 female full-time workers

\begin{tabular}{|c|c|c|}
\hline Item & $\begin{array}{c}\text { Factor } 1 \\
\text { Union } 1 \text { WFC } \\
\text { Eigenvalue }=4.51 \\
\% \text { of Variance Explained = } \\
45.11\end{array}$ & $\begin{array}{c}\text { Factor } 2 \\
\text { Union } 1 \mathrm{FWC} \\
\text { Eigenvalue }=1.79 \\
\% \text { of Variance Explained }= \\
17.87\end{array}$ \\
\hline $\begin{array}{l}\text { The demands of my work interfere } \\
\text { with my home and family life. }\end{array}$ & .825 & .161 \\
\hline $\begin{array}{l}\text { The amount of time my job takes up } \\
\text { makes it difficult to fulfil family } \\
\text { responsibilities. }\end{array}$ & .703 & .259 \\
\hline $\begin{array}{l}\text { Things I want to do at home do not get } \\
\text { done because of the demands my job } \\
\text { puts on me. }\end{array}$ & .847 & .152 \\
\hline $\begin{array}{l}\text { My job produces strain that makes it } \\
\text { difficult to fulfil family duties. }\end{array}$ & .826 & .200 \\
\hline $\begin{array}{l}\text { Due to work, I have to make changes to } \\
\text { my plans for family activities. }\end{array}$ & .838 & .155 \\
\hline $\begin{array}{l}\text { The demands of my family or } \\
\text { spouse/partner interfere with } \\
\text { work-related duties. }\end{array}$ & .206 & .765 \\
\hline $\begin{array}{l}\text { I have to put off doing things at work } \\
\text { because of demands on my time at } \\
\text { home. }\end{array}$ & .135 & .797 \\
\hline $\begin{array}{l}\text { Things I want to do at work don't get } \\
\text { done because of the demands of my } \\
\text { family or spouse/partner. }\end{array}$ & .159 & .796 \\
\hline $\begin{array}{l}\text { My home life interferes with my } \\
\text { responsibilities at work such as getting } \\
\text { to work, accomplishing daily tasks, and } \\
\text { working overtime. }\end{array}$ & .246 & .489 \\
\hline $\begin{array}{l}\text { Family-related strain interferes with } \\
\text { my ability to perform work-related } \\
\text { duties. }\end{array}$ & .105 & .767 \\
\hline
\end{tabular}


Table 5. Principle components analysis with varimax rotation producing two discrete factors for WLC and LWC from adaptations to the Netemeyer, et al., (1996) scale. Union 2 female full-time workers

\begin{tabular}{|c|c|c|}
\hline Item & $\begin{array}{c}\text { Factor } 1 \\
\text { Union } 2 \text { WLC } \\
\text { Eigenvalue }=4.78 \\
\% \text { of Variance Explained }= \\
47.76\end{array}$ & $\begin{array}{c}\text { Factor } 2 \\
\text { Union } 2 \text { LWC } \\
\text { Eigenvalue }=\mathbf{2 . 2 8} \\
\text { \% of Variance Explained }= \\
22.83\end{array}$ \\
\hline $\begin{array}{l}\text { The demands of my work interfere } \\
\text { with my life away from work. }\end{array}$ & .889 & .008 \\
\hline $\begin{array}{l}\text { The amount of time my job takes up } \\
\text { makes it difficult to fulfil other } \\
\text { interests. }\end{array}$ & .889 & .135 \\
\hline $\begin{array}{l}\text { Things I want to do at home do not get } \\
\text { done because of the demands of my } \\
\text { job. }\end{array}$ & .901 & .148 \\
\hline $\begin{array}{l}\text { My job produces strain that makes it } \\
\text { difficult to fulfil other responsibilities } \\
\text { and duties. }\end{array}$ & .853 & .208 \\
\hline $\begin{array}{l}\text { Due to work, I have to make changes to } \\
\text { my plans for activities away from } \\
\text { work. }\end{array}$ & .845 & .136 \\
\hline $\begin{array}{l}\text { The demands of my personal life } \\
\text { interfere with work-related duties. }\end{array}$ & .370 & .634 \\
\hline $\begin{array}{l}\text { I have to put off doing things at work } \\
\text { because of demands on my time } \\
\text { outside work. }\end{array}$ & .108 & .834 \\
\hline $\begin{array}{l}\text { Things I want to do at work don't get } \\
\text { done because of the demands of my } \\
\text { interests outside work. }\end{array}$ & .005 & .843 \\
\hline $\begin{array}{l}\text { My home life interferes with my } \\
\text { responsibilities at work. }\end{array}$ & .122 & .830 \\
\hline $\begin{array}{l}\text { Personal life strains interfere with my } \\
\text { ability to perform work-related duties. }\end{array}$ & .009 & .666 \\
\hline
\end{tabular}


Table 6. Confirmatory Factor Analysis - Comparative fit indices and residual-based fit indices showing goodness of fit of specified models for WLC/LWC and WFC/FWC scales

\begin{tabular}{|c|c|c|c|}
\hline & & $\begin{array}{l}\text { WLC \& } \\
\text { LWC }\end{array}$ & $\begin{array}{c}\text { WFC \& } \\
\text { FWC }\end{array}$ \\
\hline \multicolumn{4}{|c|}{$\begin{array}{l}\text { Goodness of fit } \\
\text { indices }\end{array}$} \\
\hline NFI & $=$ & 0.95 & 0.95 \\
\hline NNFI & $=$ & 0.95 & 0.94 \\
\hline CFI & $=$ & 0.96 & 0.96 \\
\hline IFI & $=$ & 0.96 & 0.96 \\
\hline MFI & $=$ & 0.90 & 0.91 \\
\hline GFI & $=$ & 0.94 & 0.95 \\
\hline \multirow[t]{2}{*}{ AGFI } & $=$ & 0.90 & 0.92 \\
\hline & $\begin{array}{c}\text { Residual-based fit } \\
\text { indices }\end{array}$ & & \\
\hline RMR & $=$ & 0.384 & 0.155 \\
\hline $\begin{array}{l}\text { Standardised } \\
\text { RMR }\end{array}$ & \multicolumn{2}{|c|}{ RMR } & 0.048 \\
\hline RMSEA & $=$ & 0.083 & 0.076 \\
\hline $90 \%$ confiden & & & \\
\hline $\begin{array}{l}\text { interval of } \\
\text { RMSEA }\end{array}$ & $=$ & 0.066 & 0.064 \\
\hline
\end{tabular}


Table 7. Pearson Correlation between WFC, FWC, organisational identity, turnover intention, organisational culture and GHQ: Union 1 (U1) and Union 2 (U2) female full-time workers with and without children

\begin{tabular}{|c|c|c|c|c|c|c|c|}
\hline \multirow[t]{2}{*}{$\begin{array}{l}\text { Children } \\
\text { U1. } N=172 \\
\text { U2. } N=202 \\
\text { No Children } \\
\text { U1. } N=430 \\
\text { U2. } N=120\end{array}$} & $\begin{array}{l}\text { Turnover } \\
\text { Intention }\end{array}$ & $\begin{array}{l}\text { Organisational } \\
\text { Culture }\end{array}$ & $\begin{array}{l}\text { (U1)WFC } \\
\text { (U2)WLC }\end{array}$ & \multicolumn{2}{|c|}{$\begin{array}{l}\text { (U1)FWC } \\
\text { (U2)LWC }\end{array}$} & \multicolumn{2}{|c|}{ GHQ } \\
\hline & $\begin{array}{c}\text { Children No } \\
\text { Children }\end{array}$ & $\begin{array}{c}\text { Children No } \\
\text { Children }\end{array}$ & $\begin{array}{l}\text { Children } \quad \text { No } \\
\text { Children }\end{array}$ & Children & $\begin{array}{r}\text { No } \\
\text { Children }\end{array}$ & Children & $\begin{array}{l}\text { No } \\
\text { ldren }\end{array}$ \\
\hline \multirow[t]{2}{*}{$\begin{array}{l}\text { Organisational } \\
\text { Identity }\end{array}$} & $\begin{array}{c}\text { U1 } \\
-.519^{* *} \quad-.593^{* *} \\
\text { U2 }\end{array}$ & $\begin{array}{cl}\text { U1 } & \\
.388 * * & .430 * * \\
\text { U2 } & \end{array}$ & $\begin{array}{cl}\mathrm{U} 1 \\
-.261 * * & -.220 * * \\
\mathrm{U} 2\end{array}$ & -.018 & $\begin{array}{l}1 \\
-.082 \\
2\end{array}$ & $-.177^{*}$ & $-.260 * *$ \\
\hline & $-.469^{* *} \quad-.517 * *$ & $.399 * * \quad .276^{* *}$ & $-.119 \quad-.213^{*}$ & $-.168^{*}$ & -.027 & -.122 & $-.344 * *$ \\
\hline \multirow[t]{2}{*}{$\begin{array}{l}\text { Turnover } \\
\text { Intention }\end{array}$} & & \multirow{2}{*}{$\begin{array}{c}\mathrm{U} 1 \\
-.318^{* *} \quad-.286^{* *} \\
\mathrm{U} 2 \\
-.290^{* *} \quad-.308^{* *} \\
\end{array}$} & $\begin{array}{cl}\mathrm{U} 1 \\
.243^{* *} & .257^{* *} \\
& \mathrm{U} 2\end{array}$ & .068 & $\begin{array}{l}1 \\
2.079 \\
2\end{array}$ & $.185^{*}$ & $.276^{* *}$ \\
\hline & & & $.221 * * \quad .359^{* *}$ & $.154^{*}$ & .119 & $.233 * *$ & $.327 * *$ \\
\hline \multirow[t]{2}{*}{$\begin{array}{l}\text { Organisational } \\
\text { Culture }\end{array}$} & & & $\begin{array}{c}\text { U1 } \\
-.523 * * \quad-.400 * * \\
\text { U2 }\end{array}$ & $-.238 * *$ & $\begin{array}{l}1 \\
-.149^{* *} \\
2\end{array}$ & $-.222 * *$ & $-.274 * *$ \\
\hline & & & $-.392 * * \quad-.460 * *$ & $-.174 *$ & $-.189 *$ & $-.199 * *$ & $-.399 * *$ \\
\hline (U1) WFC & & & & $.467 * *$ & $\begin{array}{l}1 \\
.408 * *\end{array}$ & $.293 * *$ & $.321^{* *}$ \\
\hline (U2) WLC & & & & $.329 * *$ & $.385^{* *}$ & $.232 * *$ & $.382 * *$ \\
\hline (U1) FWC & & & & & & $.340 * *$ & $.138 * *$ \\
\hline (U2) LWC & & & & & & $.151^{*}$ & .052 \\
\hline
\end{tabular}

** Correlation is significant at the 0.01 level (2-tailed)

* Correlation is significant at the 0.05 level (2-tailed) 
Table 8. Fisher's z r transformations between variables in Union 1 and Union 2 - Female full-time workers with and without children

\begin{tabular}{|c|c|c|c|c|c|c|c|c|c|c|}
\hline Union 1 & $\begin{array}{l}\text { Org Id / } \\
\text { WFC }\end{array}$ & $\begin{array}{l}\text { Org Id / } \\
\text { FWC }\end{array}$ & $\begin{array}{c}\text { Org Id / } \\
\text { GHQ }\end{array}$ & $\begin{array}{l}\mathrm{TI} / \\
\mathrm{FWC}\end{array}$ & $\begin{array}{c}\text { TI / } \\
\text { GHQ }\end{array}$ & $\begin{array}{l}\text { Org Cul } \\
\text { / WFC }\end{array}$ & $\begin{array}{l}\text { Org Cul } \\
\text { / FWC }\end{array}$ & $\begin{array}{l}\text { WFC / } \\
\text { FWC }\end{array}$ & $\begin{array}{c}\text { WFC / } \\
\text { GHQ }\end{array}$ & $\begin{array}{c}\text { FWC / } \\
\text { GHQ }\end{array}$ \\
\hline $\begin{array}{c}\text { With } \\
\text { children } \\
\text { Without } \\
\text { children }\end{array}$ & $\mathrm{r}=-.261$ & $r=.018$ & $r=-.177$ & $r=.068$ & $\mathrm{r}=.185$ & $r=.523$ & $r=-.238$ & $\begin{array}{l}r=.467 \\
r=.408\end{array}$ & $\begin{array}{l}r=.293 \\
r=.321\end{array}$ & $\begin{array}{l}r=.340 \\
r=.138\end{array}$ \\
\hline Union 2 & $\begin{array}{c}\text { Org Id / } \\
\text { WLC }\end{array}$ & $\begin{array}{l}\text { Org Id / } \\
\text { LWC }\end{array}$ & $\begin{array}{c}\text { Org Id / } \\
\text { GHQ }\end{array}$ & $\begin{array}{c}\mathrm{TI} / \\
\mathrm{LWC}\end{array}$ & $\begin{array}{c}\mathrm{TI} / \\
\mathrm{GHQ}\end{array}$ & $\begin{array}{l}\text { Org Cul } \\
/ \quad \text { WLC }\end{array}$ & $\begin{array}{l}\text { Org Cul } \\
/ \quad \text { LWC }\end{array}$ & $\begin{array}{l}\text { WLC / } \\
\text { LWC }\end{array}$ & $\begin{array}{c}\text { WLC / } \\
\text { GHQ }\end{array}$ & $\begin{array}{c}\mathrm{LWC} / \\
\mathrm{GHQ}\end{array}$ \\
\hline $\begin{array}{c}\text { With } \\
\text { children } \\
\text { Without } \\
\text { children }\end{array}$ & $r=-.119$ & $r=.168$ & $r=-.122$ & $\mathrm{r}=.154$ & $\mathrm{r}=.233$ & $r=-.392$ & $r=-.174$ & $\mathrm{r}=.329$ & $\mathrm{r}=.232$ & $\mathrm{r}=.151$ \\
\hline $\begin{array}{c}Z \text { result } \\
\text { (2-tailed) }\end{array}$ & & & & & & & & & & \\
\hline $\begin{array}{c}\text { With } \\
\text { children }\end{array}$ & $\begin{array}{c}Z=1.38 \\
\text { (n.s.) }\end{array}$ & $\begin{array}{c}Z=1.45 \\
\text { (n.s.) }\end{array}$ & $\begin{array}{c}\mathrm{Z}=\mathbf{0 . 5 3} \\
\text { (n.s.) }\end{array}$ & $\begin{array}{c}\mathrm{Z}=\mathbf{0 . 8 2} \\
\text { (n.s.) }\end{array}$ & $\begin{array}{c}\mathrm{Z}=0.49 \\
\text { (n.s.) }\end{array}$ & $\begin{array}{c}Z=1.62 \\
\text { (n.s.) }\end{array}$ & $\begin{array}{c}\mathrm{Z}=0.65 \\
\text { (n.s.) }\end{array}$ & $\begin{array}{c}Z=1.60 \\
\text { (n.s.) }\end{array}$ & $\begin{array}{c}\mathrm{Z}=\mathbf{0 . 6 7} \\
\text { (n.s.) }\end{array}$ & $\begin{array}{l}Z=1.94 \\
(p=.05)\end{array}$ \\
\hline children & & & & & & & & $\begin{array}{c}Z=.029 \\
\text { (n.s.) }\end{array}$ & $\begin{array}{c}\mathrm{Z}=0.65 \\
\text { (n.s.) }\end{array}$ & $\begin{array}{c}Z=0.87 \\
\text { (n.s.) }\end{array}$ \\
\hline
\end{tabular}

